\title{
Interactive comment on "SHORT COMMUNICATION: Massive Erosion in Monsoonal Central India Linked to Late Holocene Landcover Degradation” by Liviu Giosan et al.
}

\section{Liviu Giosan et al.}

Igiosan@whoi.edu

Received and published: 27 September 2017

Response: We thank Y. Kulkarni for his suggestions that are useful to improve our work. We respond here to his second comment, largely identical to his first, assuming that the last comment is the final one.

Referee: The short communication is based on the landcover, soil and its erosion from two different zones of lithologies present in Godavari Drainage Basin (GDB) which is also previously discussed by Kulkarni et al. (2015) based on the mineral magnetic studies of Godavari sediments and Bay of Bengal sediments. Their study show the general increasing trend in ferrimagnetic concentration in middle Bay of Bengal sediments sug- 
gesting to the dominance of Deccan source over quartzo-feldspahthic source for Late Holocene. They suggested the combine effect of distinct lithological units, geomorphic setup and spatial distribution of monsoonal rainfall plays an important role in sediment generation in GDB. Previously Sangode et al. (2001) also suggested the dominance of Peninsular Source over Himalayan source in Bay of Bengal sediments. Kulkarni et al (2014) based on mineral magnetic study inferred the dominant Deccan basaltic source over the floodplains of Godavari River for entire stretch as a result of intense weathering of Deccan plateau. Recently Cui et al. (2017) based on organic carbon and mineral magnetic analysis of well dated (AMS 14C) Godavari delta core 'CY' suggested the increasing Deccan basaltic source during Late Holocene particularly after nearly 6 cal ka BP. Their study also show the significant increase in ferrimagnetic minerals from nearly 3.2 to 3.1 cal. ka BP attested to severe decline in vegetation in Deccan plateau.

Response: These are very useful works and we note them and cite as follows:

"The Nd isotopic signal points to an increase in the Deccan sedimentary output at the time, after a muted variability earlier in the Holocene when the Indian Craton consistently provided $\sim 50-60 \%$ of the sediments (Fig. 2; see Supplementary Materials). Ferrimagnetic minerals interpreted as originating from the Deccan (Sangode et al., 2001; Kulkarni et al., 2014) also increase in late Holocene sediments in the Godavari delta (Cui et al., 2017) and Bay of Bengal (Kulkarni et al., 2015) supporting our interpretation. Augmented Deccan inputs were suggested for the Godavari delta (Cui et al., 2017) even earlier after $\sim 6000$ years ago, in step with the initial aridification."

We also now cite Cui et al. (2017), paper published after our manuscript was submitted, several times where appropriate.

Referee: Majority of $\mathrm{CMZ}$ is represented by Pranhita River basin rather than upper Godavari and the mixing may have a complex role in Godavari onwards is not considered.

Response: We carefully use the term "upper basin", which includes much of the Pranhita basin, but agree that mixing would be a good topic for future detailed work.

\section{ESurfD}

Interactive comment
Printer-friendly version

Discussion paper

2 
Referee: Besides this, the Bikshamaiah and Subramaniyan (1980) although given detail account on chemical and sediment mass transfer in GDB and established some controlling factors for same, they did not classify the geology of GDB as two major geological units. The part of Godavari River in the Godavari graben is flowing above the Gondwana and Purana sedimentary units which although accounts for about $11 \%$ of basin (Biksham and Subramaniyan, 1988) but acts as major lithounit in main channel as well as in Pranhita River (A major tributary of Godavari).

Response: Geochemically and especially isotopically our classification stands and has been used regularly when describing marine cores in the region (e.g., Mazumdar et al., 2015). The reason is that Gondwana and Purana sediments preserve the craton signature where they originated (e.g., Amarasinghe et al., 2014) especially for conservative properties as $\mathrm{Nd}$, which is vastly different than the young Deccan signature.

Refs:

Amarasinghe, U., Chaudhuri, A., Collins, A.S., Deb, G., Patranabis-Deb, S., 2014. Evolving provenance in the Proterozoic Pranhita-Godavari Basin, India. Geoscience Frontiers.

Mazumdar, A., Kocherla, M., Carvalho, M.A., Peketi, A., Joshi, R.K., Mahalaxmi, P., Joao, H.M., Jisha, R., 2015. Geochemical characterization of the Krishna-Godavari and Mahanadi offshore basin (Bay of Bengal) sediments: a comparative study of provenance. Mar. Pet. Geol. 60, 18-33.

Interactive comment on Earth Surf. Dynam. Discuss., https://doi.org/10.5194/esurf-2017-35, 2017. 